\title{
Reflection on Decentralization Reform of Financial Management in Elementary and Secondary Education In Kosovo
}

\author{
Ragip Gjoshi \\ Kristaq Kume
}

University "Aleksander Moisiu" Durrës. Albania

\section{Doi:10.5901/jesr.2014.v4n3p273}

\begin{abstract}
Decentralization of financial resources management in elementary and secondary education institutions is one of the priority actions being implemented in Kosovo. This process is taking place in line with the current global trend, according to which the increased autonomy and diversity in financial sources are the basic conditions for enhancing the capacity and quality of these institutions. Public institutions of elementary and secondary educational system in Kosovo are the object of this study. State budget is their main financial source. Decentralization policies and incentives for financial autonomy currently aim at promoting and enhancing the capacity of these institutions to generate financial income and increase self administration of these revenues. The purpose of this study is the comparative analysis of best practices in EU countries, achievements, challenges and expectations in the implementation of financial autonomy in elementary and secondary educational system in the Republic of Kosovo.
\end{abstract}

Keywords: financial autonomy, elementary and secondary education system, financial sources, budget.

\section{Introduction}

Kosovo, as the newest state in Europe is developing a series of reforms that affects almost all areas and different aspects of life and social and economic institutions of the country. The reform of the educational system is among the most important and currently represents one of the main priorities of Kosovo's Government. This reform is taking place at all levels and in all components of the educational system. It is a complex reform with vertical and horizontal extension. Its realization is modeled as a product of interaction and cooperation between institutions of central and local government and local communities. The reform for decentralization of financial administration in elementary and secondary educational system is distinguished by its importance, complexity and difficulties, that must be overcome in order to be implemented (Jürgen-Tillmann, K.1994; Pastuović, N.1999). The reform aims at developing the necessary capacities that will make possible the effective financial autonomy of these institutions. The development of an appropriate culture and self management of financial resources, in addition to developing the capacities to generate income from the institutions themselves, are among the main objectives of the reform currently being implemented in the public educational system in Kosovo.

\section{Financal Model of Elementary and Secondary Education in Kosovo}

In general terms, the financing of educational institutions, well as in other European countries, is obtained from several sources: public funds, donations from international and local projects, and income from its activities (M. Atkinson, M., et al. 2005). The main purpose in the use of these funds is to develope the educational institution performances in order to realize effective curricula and services for the community education, create an effective culture of intersection between learning and other activities, oriented resource cunsumption, development of learning process and overall school achievements.

The construction of a functional school funding system, which should reflect the actual needs of the education system in Kosovo, is defined as a priority by the Education Strategic Plan (p.5). The research to assess teachers and administrative staff needs, taking into account the expected development in the educational system, is among the most important issues addressed by this plan. The main instrument in order to realize this study and to implement its results is 
the utiliziation of the Elementary and Secondary Education Financing Formula ${ }^{1}$. This formula is a new instrument through which the Kosovo government has approached the method of financing and budget management in accordance with the principles of power and authority decentralization in the field of education from central to local level. This formula was first implemented as a pilot project, to be extended later to all municipalities. It defines the basic principles for the allocation of budgetary funds for schools, counting on some parameters and indicators, which bring synthetic information of school basic features and its image.

This formula is based on the two following principles²:

- Involvement in the Financial Formula of the Municipality Budget of schools budgetary funds;

- Management Autonomy of schools financial funds.

These two principles are very important for the formation of a new understanding of the role, responsibilities, rights and obligations of different actors that are part of elementary and secondary education system. In order to successfully implement this new formula, an intensive process of training professional and appropriate staff at the municipality level and in the educational institutions si required. It is necessary to form a new leadership which shall take over and implement this new funding formula. For this purpose, the World Bank in cooperation with the Ministry of Education, during the 2009-2013 period, has supported and implemented a large number of projects. These projects aimed at improving the quality of teaching conditions and the support on creating and developing administrative and management skills of administrative and leading school staff in order to obtain and use financial funds.

The financial formula of elementary and secondary education system follows the algorithm shown in No.1

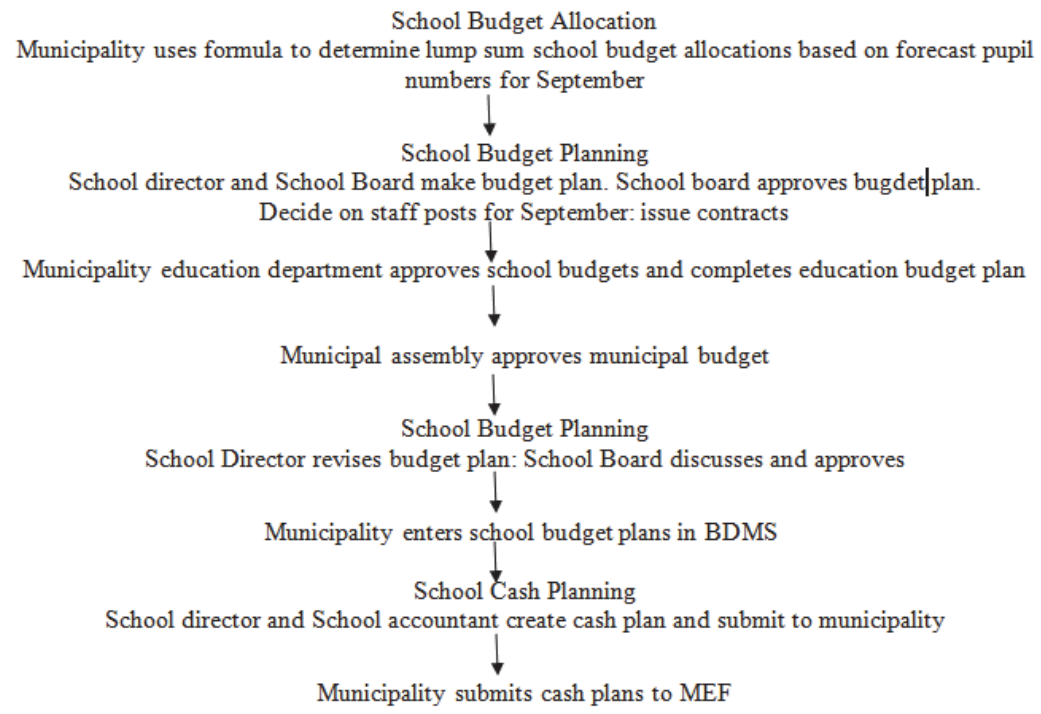

Unlike the previous formula, this formula increases the essential role of local institutions and schools, in planning and using the school budget. It provides a procedure builded upon the basis of the principle of decision making decentralization. In this way it creates the opportunities to implement the right corrections of the financial system of these public institutions in Kosovo, by creating real options for increasing its cohesiveness with that of developed countries (Meltsner A., et al., 1973; Lipičnik, B. 1999; Matić, I. 2005). The implementation of this formula is a process which, with all the associated difficulties, is foreseen to be implemented at the local and central level, at the end of 2014 (Education Strategic Plan, p.75). For this reason the legislator has adopted the necessary amendments. Pursuant to them the schools, as basic units of elementary and secondary education, have much more freedom and larger spaces on using various financial resources. They have increased opportunities to develop their capacities and responsibilities for fulfilling the mission. On the basis of the current legal framework, financial inputs for schools of elementary and secondary

\footnotetext{
1 The funding formula was developed with the help of the Education Institutional Development (IDEP) Project supported by the World Bank. Its implementation started as a pilot project in three municipalities in 2009 to serve as a mechanism for budget sharing according the respective categories at the national level.
}

2 IDEP, Component 1, Report nr 3, November, 2010; 
education system in Kosovo may come from: (i) central and local public funds, (ii) donations from other institutions outside the system, (iii) income from school activities, (iv) grant in the framework of international cooperation.

Public funds are used primarily as remuneration for employees, teachers and administrative staff. They also cover material and maintenance costs, such as heating, electricity etc... The amont is defined depending on the number of students, programs / professions and employees. Schools in rural remote areas are treated with priority, providing free transportation for them, in order to prevent the decline in numbers of students caused by the distance from the center. Compared with other countries, the financing of elementary and secondary education system in in Kosovo with public funds, in relation to GDP, is low, while population needs for education at this level is high (Dowling, A. 2007). Kosovo's population is among the youngest in Europe, with an average of around 23. 4 years. Public funds are the main source of financial inputs for elementary and secondary education schools in Kosovo. Currently other financial sources are modest. This situation is similar to that faced in some other countries such as New Zealand, Ireland, Austria, France, Norway (M. Atkinson, et al. 2005).

\section{Initiatives to Increase the Managerial Capacity for Planning Development in Schools}

Requirements for continuous developments of elementary and secondary education system is closely connected with population needs for education. A fifth of the global population requires it. Consequently the budget for education expenses is estimated to reach the level of about $25 \%$ of the state budget (Pastuovic, N. 1999; Gary, K., et al. 2009). The expectations in Kosovo are at the same level. Under these circumstances, decentralization aiming at increasing the financial autonomy of educational institutions is a contemporary need. Its success affects the success of the elementary and secondary education system (Guideline - management of education systen in commune level, 2002). In accordance with this document, the school is the principal decision making and implementation unit for its budget utilization. Meanwhile, we are facing a different situation. In many cases the municipality authorities decide on the assessments of needs for services and goods to be covered by the school budget and remuneration costs and capital investments are defined and administered by central government units. In order to change this situation and create the necessary conditions and capacities for implementing the decentralization reform and for more financial autonomy, the World Bank funded the "Improving Education Participation (EPIP) (World Bank 2003) project, followed by the -"On the Development of Educational Institutions" (World Bank 2007) project. These projects sought to strengthen managerial performance in schools, capacity building for budget planning and use, increasing the role of councils, developing municipality's capacities to design financial plans and funds allocation effectively, equally and in time.

\section{On Indicators for Calculating the Specific Education Grant}

The main indicators used for calculating public funds for elementary and secondary education system in the Republic of Kosovo are: number of students, ratio student / teacher, indicators for calculating the needs for administrative and auxiliary staff, the average wage at municipality level, indicators for goods, services, and small capital. The calculation of these indicators is done depending on current policies and their expected developments on the elementary and secondary education, at municipality level. Referring to the academic year 2013 -2014 statistics, the number of students in the elementary and secondary system in Kosovo, is given in Table No. 1

Table No. 1: Number of students - 2013-2014 academic year

\begin{tabular}{|l|c|c|}
\hline \multirow{2}{*}{ Level of education } & \multicolumn{2}{|c|}{ Registered Students } \\
\cline { 2 - 3 } & Total & $\%$ \\
\hline Kindergarten & 27,847 & 6.4 \\
\hline Elementary & 296,902 & 68.1 \\
\hline Special Schools & 601 & 0.14 \\
\hline High Schools & 45,482 & 10.4 \\
\hline Professional Schools & 65,133 & 14.9 \\
\hline Total & $\mathbf{4 3 5 , 9 6 5}$ & 100 \\
\hline
\end{tabular}

Table No. 2 contain data of "student / teacher ratio" in large communities and in remote areas with small population. 
Table No. 2: Ratio Student / teacher

\begin{tabular}{|l|c|c|}
\hline \multirow{2}{*}{ Level of education } & \multicolumn{2}{|c|}{ Community Size } \\
\cline { 2 - 3 } & Large & Small \\
\hline Kindergarten & 12.0 & 12.0 \\
\hline Elementary & 21.3 & 14.2 \\
\hline Special & 5.5 & 5.5 \\
\hline High Schools & 21.3 & 14.2 \\
\hline Professional & 17.2 & 11.5 \\
\hline Mountains Areas & 14.3 & 14.2 \\
\hline
\end{tabular}

Figure No. 1 provides the total number of teachers and administrative support staff.
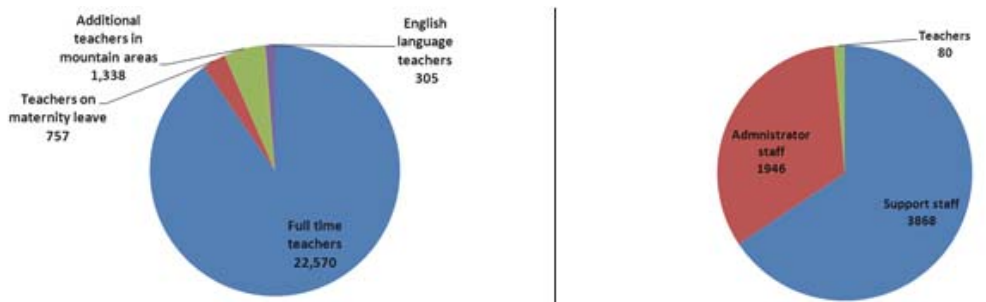

Figure no.1: Number of teachers and administrative staff

Figure No. 2 gives the expenses for administrative and support staff and other expenses planned for elementary and secondary education system during the academic year 2013-2014.

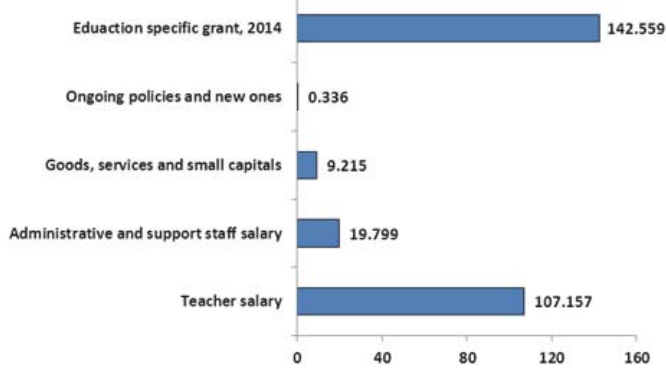

Figure No.2: Planning for the expenditure of public funds

Table No. 3. Indicators used for planning costs for: goods, services and small capitals

\begin{tabular}{|l|l|}
\hline Goods, services / students of large communities & 23 Euro \\
\hline Goods, services / students of small communities & 25 Euro \\
\hline Good, services for kindergarten & 1500 Euro \\
\hline Goods, services for high schools & 3250 Euro \\
\hline Capital expenditure for student & 7 Euro \\
\hline
\end{tabular}

Referring to these indicators, the budget responsibility for education in elementary and secondary education sector and preschools in Kosovo, has been transferred to municipalities ${ }^{3}$. The funds are provided by the government for each municipality in the form of a grant to assist them in implementing their responsibilities.

${ }^{3}$ Arrangements for the implementation of the transfer of financial responsibilities to municipalities are embodied in the Memorandum of Understanding signed by the Department of Education and Science, UNMIK Regulation, Department of Local Administration and the Central Fiscal Authority in October 2001. 
Referring to the changes associated with increased decentralization, municipalities are expected to transfer some of their rights and duties of financial administration to the headmasters and schools administration boards.

Municipalities are now in-charged with the obligation to inform the community on how schools budgets are used. They should cooperate with the school management staff not only for planning and using the annual budget but also to pursue its ongoing implementation.

\section{Conclusions}

The Republic of Kosovo is undertaking an intensive process of reforms in elementary and secondary education system. Its main objective is increasing the level of decentralization in decision making for planning and use of budgetary funds.

Relying on the help of the international community, this reform aims at the implementation of a management system with the same features with those of modern and developed systems.

The predicted amendments will enable the implementation of a new system, essentially different from the current one.

The target of this reform is to enable schools in order to realize not only the educational function but also the financial planning and management one.

The financial autonomy is foreseen to take place as process of cooperation and coordination of rights and duties between school governing bodies and central and local authorities.

The expected developments in decentralization of elementary and secondary education institutions funding is strongly linked with developments of schools curricula's, visions, goals and content.

This reform is considered, in Kosovo as one of the most important reforms with multidimensional purposes.

Its implementation is a gradual process in which are interwoven experiences and achievements realized so far in similar reforms implemented in developed countries.

\section{References}

Atkinson, M., Lamont, E., Gulliver, C., White R., Kinder K. 2005. "School Funding: a review of existing models in European and OECD countries" NFER.

Dowling, A. 2007. Australia's School Funding System.

Hanbook of Management Education in Local Level, 2002

Gary, K., Clabaugh, E., Rozicki, G. 2009.: The School as an organization

Jürgen-Tillmann, K. 1994.: Teorije škole, Education, Zagreb.

Lipičnik, B. 1999. "Organizacija podjetja", Univerza v Ljubljani, Ekonomska fakulteta, Ljubljana

Ligji për Arsimin në Komunat e Republikës së Kosovës http://www.kgjks.org/repository/docs/gazeta/30.albanian.pdf?phpMyAdmin $=b c 08 d 53405236 \mathrm{fb} 8 \mathrm{e} 339520 \mathrm{de} 8 \mathrm{ef} 645 \mathrm{f}$

Lockhart, J. 2011. "How to market your school" Roman and Littlefield Education.

Matić, I. 2005: "Teorije organizacije", vježbe, Ekonomski fakultet, Katedra za management, Split

Meltsner, A., Kast, G., Kramer, J., Nakamura R. 1973 "Political Feasibility of Reform in School Finance: The Case of California" Praeger. Pastuović, N. 1999. Edukologija, Znamen, Zagreb.

Strategic Plan of Education in Kosovo. 2011-2016 http://www.uni-pr.edu/getattachment/ b0997082-4539-497d-9622-706294c9307/Planistrategjik-i-arsimit-ne-Kosove-2011-2016.aspx

World Bank 2003. Projekti për Përmirësimin e Pjesëmarrjes në Arsim (PPPA) 0 
